\title{
Advances on Biomonitoring of Organophosphorus and Organochlorine Pesticides
}

\author{
Ioanna Katsikantamia, Matthaios P. Kavvalakis ${ }^{a}$, \\ Manolis N. Tzatzarakis ${ }^{\mathbf{a}}$, Alexander E. Nosyrev, \\ Elena Vakonaki ${ }^{a}$ and Aristidis M. Tsatsakis*a \\ ${ }^{a}$ Laboratory of Toxicology Science \& Research \\ Medical School, University of Crete \\ P.O. Box 1393, Heraklion, 71003, Crete, Greece \\ ${ }^{b}$ I.M. Sechenov First Moscow State Medical University \\ 8-2 Trubetskaya Str., Moscow, 119991, Russia
}

Organophosphorus (OPs) and organochlorine (OCs) pesticides are synthetic organic compounds used mainly in agriculture to manage pest problems. Human is occupationally and environmentally exposed to pesticides via inhalation, ingestion and skin absorption. When the pollutant enters human body it is rapidly metabolized to more toxic compounds than the parent compound. Their ability to interfere with biochemical and metabolic pathways in humans makes them compounds of high concern. Acute and chronic exposure has been linked with neurological, cardiovascular, birth effects and male infertility. Human exposure to pesticides is estimated by measuring their metabolites in biological tissues and fluids such as blood, urine, amniotic fluid and hair. In this review study advances on biomonitoring of pesticides are presented. Measured levels of pesticides in urine matrices, amniotic fluid, meconium and hair are presented in order to monitor the human burden and biomonitoring data between occupationally and environmentally exposed populations are being compared.

Keywords: pesticides, biomonitoring, human toxicity, occupational exposure, environmental exposure.

Citation: Katsikantami I., Kavvalakis M.P., Tzatzarakis M.N., Nosyrev A.E., Vakonaki E., Tsatsakis A.M. Advances on biomonitoring of organophosphorus and organochlorine pesticides. J. Sib. Fed. Univ. Biol., 2017, 10(2), 153-170. DOI: 10.17516/1997-1389-0019.

(c) Siberian Federal University. All rights reserved

* Corresponding author E-mail address: tsatsaka@uoc.gr 


\title{
Достижения в области биомониторинга \\ фосфорорганических
}

и хлорорганических пестицидов

\author{
И. Кацикантами ${ }^{\text {a }}$ М.П. Каввалакис ${ }^{a}$ М.Н. Цацаракис \\ А.Е. Носырев ${ }^{0}$, Е. Ваконаки ${ }^{\mathrm{a}}$, А.М. Тсатсакис ${ }^{\mathrm{a}}$ \\ a Лаборатория токсикологических наук \\ Медицинский институт, Университет Крита \\ Греция, Крит, 71003, Ираклион, п/я 1393 \\ ${ }^{\sigma}$ Первый Московский государственный медицинский университет \\ им. И.М. Сеченова \\ Россия, 119991, Москва, ул. Трубецккая, 8-2
}

Фосфорорганические и хлорорганические пестициды - это синтетические органические соединения, используемье преимущественно в сельском хозяйстве для борьбы с вредителями. Люди подвергаются воздействию пестицидов в процессе профессиональной деятельности и при контакте с зараженной средой через их вдыхание, потребление с пищей и поглощение кожей. При попадании в организм человека поллютант быстро метаболизируется до более токсичных соединений, чем исходное вещество. Их способность взаимодействовать с биохимическими и метаболическими путями в человеческом организме делает их потенциально опасньми соединениями. Обнаружена связь между острым и хроническим воздействием пестицидов и неврологическими и кардиоваскулярными эффектами, врожденными отклонениями и мужским бесплодием. Оиченка воздействия пестицидов на организм человека проводится путем измерения их метаболитов в биологических тканях и жидкостях, таких как кровь, моча, амниотическая жидкость, а также в волосах. В данном обзоре представлены достижения 8 области биомониторинга пестищидов. Для оценки нагрузки на человека приведены измеренные уровни пестицицов в моче, амниотической жидкости, меконии и волосах. Проведено сравнение популяиий, подвергшихся воздействию пестищидов в связи с производственной деятельностью и при контакте с окружающей средой.

Ключевые слова: пестициды, биомониторинг, токсичность для человека, профессиональное воздействие пестицидов, воздействие пестицидов в окружающей среде.

\section{Introduction}

Human exposure to pesticides

Pesticides are synthetic organic compounds used mainly in agriculture to manage pest problems. Organochlorine (OCs) and organophosphorus (OPs) pesticides were firstly introduced in market in 1940s. OCs comprise a variety of chlorinated organic compounds with high toxicity, slow degradation and bioaccumulation. Their overwhelming majority has been globally banned since 1972 . Representative compounds in this group include Dichloro-diphenyl-trichloroethane or 1,1,1-trichloro-2,2-bis(4-chlorophenyl)ethane 
(DDT), methoxychlor, dieldrin, chlordane, toxaphene, lindane and benzene hexachloride (Fig. 1). OPs are the most widely used agricultural chemicals which replaced OCs because of their rapid degradation in the environment. However, they have greater acute toxicity including headaches, nausea and cardiovascular effects. The most notable compounds in this group include fenthion, parathion and chlorpyrifos which are under strict regulation (CDC, 2009; US EPA, 2013). OPs tend to be replaced with pyrethroids which were introduced in market in 1960s.

Human is multiply exposed to pesticides via inhalation, ingestion and skin absorption. Population can be classified in groups with occupational or environmental exposure depending on the pathway of exposure to pesticides. Environmental exposure of the general population in metropolitan or rural areas occurs through dietary habits, indoor/ outdoor air and house dust which may include household use of insecticides and drinking water or consumption of food containing residues of the pollutants (Tsakiris et al., 2013; Tsakiris et al., 2015; Tsatsakis et al., 2003). Occupationally exposed population group includes farm workers, pesticide applicators, sprayers and harvesters. Another group includes accidentally exposed population and acute poisonings via inhalation or ingestion (Bradman et al., 2007; Rothlein et al., 2006; Thompson et al., 2008; Wilson et al., 2010). The human risk and the severity of adverse effects are determined by the total exposure, which depends on the route or exposure pathway and the type of the pesticide (EFSA, 2008). Each category of pesticide is reported to have different toxicity in humans depending on the mode of action, the metabolic pathways, the lipophilic character of the compound, the dose, the duration of exposure, and the exposure route. All pesticides are compounds that interfere with biochemical and metabolic pathways to reach their aim and be effective against insects. However, their toxicity is not specific and also humans are at risk.

All pesticides affect mainly the central nervous system. When a pesticide enters human body it is rapidly metabolized to more toxic compounds than the parent compound (Barr et al., 2004; Tyler et al., 2000). Exposure to OPs induces inhibition of the acetylcholinesterase enzyme (AChE) which consequently causes overstimulation by the excess of acetylcholine (Ach). It seems that OPs disrupt the glucose homeostasis leading to elevated serum glucose levels (Amanvermez et al., 2010; Everett and Matheson, 2010). Chronic exposure to OPs has been linked to neurological, psychiatric and cardiac effects, birth effects including teratogenicity, cancer and eye defects

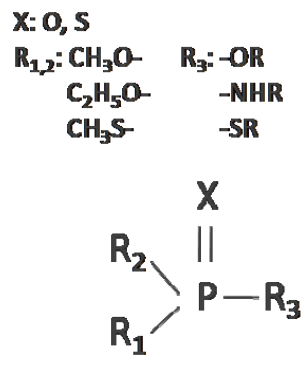

Organophosphabes

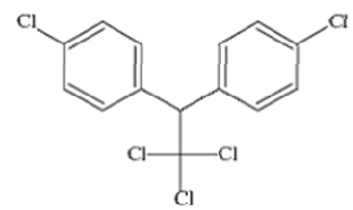

DDT

Fig. 1. Chemical structures of organophosphates (OPs) and DDT (organochlorine). The $\mathrm{R}_{3}$ group in OPs' structure determines the physicochemical properties of the pesticide 
(PAN-UK.ORG). OPs are reported to be mutagenic, carcinogenic (Dolapsakis et al., 2001; Sarabia et al., 2009), cytotoxic (Giordano et al., 2007), genotoxic (Cakir and Sarikaya, 2005), teratogenic (Kang et al., 2004) and immunotoxic (Yeh et al., 2005). OCs are persistent lipophilic compounds that remain in the human body, they are not metabolized but they tend to accumulate in organ tissues (Androutsopoulos et al., 2013). OCs are possibly related with obesity, adipogenesis and insulin levels (Casals-Casas and Desvergne, 2011; Lee et al., 2011).

\section{Biomonitoring}

Human exposure to pesticides is estimated by measuring their biomarkers (parent compounds and/or their metabolites) in biological tissues and fluids such as blood, urine, amniotic fluid and hair, a method called "Biomonitoring". It is an essential technique that integrates all routes of exposure (inhalation, ingestion, dermal absorption). It is definite evidence that exposure has occurred and is applied in epidemiology studies in health sciences, toxicology and analytical chemistry. The presence of different biomarkers among biological samples provides information about the time and the severity of the exposure. Thus, chemicals in hair indicate chronic exposure while in urine and blood short term exposure. The biomonitoring data in epidemiology studies identify if the exposure is unsafe and is used for risk assessment of the exposure. The results determine the trends of exposure between different population groups, time trends in exposure and monitor the effectiveness of intervention strategies. Through statistical analysis and modeling biomonitoring is linked with health effects, clinical symptoms and diseases and evaluates the potential environmental and occupational health risk. In environmental exposures the body burden is statistically connected with lifestyle habits, indoor and passive exposure (i.e. passive smoking).

The aim of this review study is to present recent advances on biomonitoring of pesticides. A significant number of studies published in plenty journals were gathered. Measured levels of pesticides in urine matrices, amniotic fluid, meconium and hair are presented in order to monitor the burden of OPs, and OCs in human. Biomonitoring data are compared between occupationally and environmentally exposed populations. Long term and short term exposure is correlated with adverse health effects appeared in humans.

\section{Pesticide residues in foods}

Milk and olive oil are essential and nutrient components in Mediterranean diet. However, the extensive use of pesticides has resulted in their pollution with pesticides residues posing a risk for human health. Residues of fenthion and dimethoate pesticides were determined in organic and conventional olive oils collected from Crete during 1997-99 (Tsatsakis et al., 2003). Organic olive oil contained significantly lower concentrations of both organophosphorus pesticides than conventional oil. More specifically, fenthion was detected at $122.2 \mathrm{ng} / \mathrm{g}$ (1997), $145.7 \mathrm{ng} / \mathrm{g}$ (1998) and $170.2 \mathrm{ng} / \mathrm{g}$ (1999) in samples from conventional cultivations and at $21.5 \mathrm{ng} / \mathrm{g}$ (1997), $9.9 \mathrm{ng} / \mathrm{g}$ (1998) and $3.5 \mathrm{ng} / \mathrm{g}$ (1999) in samples from organic cultivations. Dimethoate was detected at $22.6 \mathrm{ng} / \mathrm{g}$ (1997), $26.4 \mathrm{ng} / \mathrm{g}$ (1998) and $27.1 \mathrm{ng} / \mathrm{g}$ (1999) in conventional olive oil and $9.8 \mathrm{ng} / \mathrm{g}$ (1997), $3.8 \mathrm{ng} / \mathrm{g}$ (1998) and $1.0 \mathrm{ng} / \mathrm{g}$ (1999) in organic olive oil. Lower levels for dimethoate were detected probably due to its higher water solubility. These values are lower than the maximum residue levels (MRLs) for olive oil according to FAO/WHO (1998) which are $1000 \mathrm{ng} / \mathrm{g}$ for fenthion and $50 \mathrm{ng} / \mathrm{g}$ for 
dimethoate. It was observed that pesticides levels were decreasing from year to year indicating a turn to organic cultivation.

Residues of DDT and its metabolites were monitored in 196 milk samples of various pasteurized commercial types collected from the Greek market (Tsakiris et al., 2015). The detected levels of DDT and its metabolites in the milk samples were lower than the Maximum Residue Levels (40 $\mu \mathrm{g} / \mathrm{kg}$ for sum of DDTs) specified in EU Commission Regulation (EC) No 149/ 2008. The $97.4 \%$ of the samples was positive for at least one DDT isomer of metabolite. Levels of DDTs and their metabolites were not significantly differentiated for conventional and organic milk. Risk assessment for DDTs and hazard index (HI) values for children were calculated and indicated that there is no significant health risk. High HI values for children at ages between 1 and 3 years old were justified due to the higher ratio of milk consumed relatively to their low body weight.

\section{Human monitoring of OPs exposure}

When OPs enter human body they are metabolized and excreted via the biological fluids. The typical metabolic reactions involve hydrolysis and oxidation giving the more reactive oxon which may bind to cholinesterase enzyme or be hydrolyzed to a dialkylphosphate (DAP) and/ or a hydroxylated organic moiety specific for each pesticide. As a result of binding to cholinesterase, the organic portion of the molecule is released. These metabolic products are highly polar and excreted in the urine, either in free form or bound to sugars or sulfates. Metabolites of OPs can be specific and non-specific. The non specific metabolites of OPs are dimethylphosphates (DMPs) like dimethylphosphate (DMP), dimethylthiophosphate (DMTP), and dimethyldithiophosphate (DMDTP) and diethylphosphates (DEPs) such as diethylphosphate (DEP), diethylthiophosphate (DETP) and diethyldithiophosphate (DEDTP). The nonspecific metabolites of OPs, DAPs, are the most commonly used indicators for biomonitoring and estimation of the cumulative OP exposure in humans (Kavvalakis and Tsatsakis, 2012; Tsatsakis et al., 2009a; Tsatsakis et al., 2010).

Assessment of acute pesticide exposure is generally based on blood and urine analysis (Barr and Needham, 2002; Margariti et al., 2007). However, the adverse health effects appeared on humans as a result of chronic exposure, have raised a worldwide concern expressed as strict regulations and bans. In this review study special emphasis is given in hair analysis due to the ability of hair testing to assess chronic exposure to OPs. The first report on measurement of DAPs in human hair came from Margariti and Tsatsakis (2009). Thirty samples from occupationally exposed population were analyzed for DEP, DMP and DMTP which were detected in $70 \%$, $40 \%$ and $20 \%$ of the samples, respectively. The detected concentrations ranged from 0.10 to 0.46 $\mathrm{ng} / \mathrm{mg}$ for all analytes.

The cases of four patients poisoned by OPs were studied by Tsatsakis and his colleagues (2012) for examine the DAPs, as biomarkers of past acute exposure to OPs in hair samples. The analyzed metabolites were DMP, DEP, DETP and DEDTP. The hair samples were cut to $1-\mathrm{cm}$ segments and were analyzed separately for the assessment of past acute exposure to chlorpyrifos, phenthoate and dimethoate. The first patient was poisoned by chlorpyrifos and its metabolites DEP and DETP were detected at high levels, 482 and $1442 \mathrm{pg} / \mathrm{mg}$ respectively, at the segment corresponding to the time of poisoning $(\mathrm{p}<0.001)$. The third patient was exposed to dimethoate and DMP was detected at level $105 \mathrm{pg} / \mathrm{mg}$ in the segment corresponding to exposure. The last patient was exposed to a small quantity of chlorpyrifos and DEP was detected at $55 \mathrm{pg} / \mathrm{mg}$ in the segment corresponding to exposure. Only for the second patient poisoned by 
phenthoate there were no observable differences among the analyzed metabolites.

In this study, DAPs were detected in all hair samples although elevated concentrations of certain metabolites were observed in segments proximate to the suicide period. These metabolites corresponded to the ones produced by the ingested parent compound. The authors conclude that measuring DAPs in human hair indicates the cumulative exposure of the individual and a high level of a certain DAP in a segment can be used for assessing past acute exposure to a specific OP pesticide.

The comparison between biomonitoring data of rural residents (group without occupational exposure) and sprayers (group with occupational exposure) revealed higher burden of the occupationally exposed group (Kokkinaki et al., 2014; Koureas et al., 2014; Tsatsakis et al., 2010). Both urine and hair matrices gave higher levels of DAPs in agricultural workers than in rural residents-control group. The detection rates of DAPs for both control and sprayers groups were high in both matrices. The median levels and the percentage detection rates are in Table 1. Data analysis revealed that these correlations are statistically significant $(\mathrm{p}<0.001)$ (Kokkinaki et al., 2014; Koureas et al., 2014). SumDAPs levels in hair samples of the sprayers are significantly higher than in the hair of control group $(\mathrm{p}<0.001)$, confirming the long-term exposure to OPs (Fig. 2).
The use of personal protective measures and hygiene behaviors has a significant impact in reducing exposure of agricultural workers to OPs. More specifically, wearing gloves and full body coveralls while handling and applying pesticides, was positively associated with lower body burden of OPs $(\mathrm{p}<0.05)$. Workers who used to change their uniform immediately after accidental spillage of pesticide had much lower urinary levels of DAPs than those who did not change their clothes (Koureas et al., 2014). The $67.5 \%$ and $40.8 \%$ of the applicators reported that they use a mask and gloves respectively while mixing or loading the pesticide and only the $32.9 \%$ usually use full body coveralls. The $76.3 \%$ change clothes immediately after application and the $23.7 \%$ are smoking while working.

Fetal exposure to OPs is estimated by the measurement of DAPs in amniotic fluid (Koutroulakis et al., 2014) and meconium (Tsatsakis et al., 2009a). Amniotic fluid (AF) samples from 415 mothers from Greece (Crete) were analyzed for DMP, DMTP, DEP, DETP, and DEDTP (Koutroulakis et al., 2014). Sums of DMPs, DEPs and DAPs ranged from 0.07 to $222.9 \mathrm{ng} / \mathrm{ml}, 0.19$ to $254.3 \mathrm{ng} / \mathrm{ml}$ and 0.05 to $252.6 \mathrm{ng} / \mathrm{ml}$, respectively. DEP and DETP were the most frequently detected metabolites with detection rates $90.5 \%$ and $74.0 \%$, respectively. DMP and DEDTP were detected at $60.0 \%$ and $39.5 \%$ of the samples, respectively. The

Table 1. The median levels and the percentage detection rates of DAPs in hair ( $\mathrm{pg} / \mathrm{mg})$ and urine samples (ng/ml) from Greek population

\begin{tabular}{|c|c|c|c|}
\hline Study & Biological Matrix & $\begin{array}{c}\text { General population } \\
(\% \text { positive samples })\end{array}$ & $\begin{array}{c}\text { Pesticide applicators } \\
(\% \text { positive samples })\end{array}$ \\
\hline Tsatsakis et al., 2010 & Hair & $301.5(63.0-96.3)$ & $1694.4(100)$ \\
\hline Koureas et al., 2014 & Urine & $11.9(81.3-99.1)$ & $24.9(97.4-100)$ \\
\hline \multirow{2}{*}{ Kokkinaki et al., 2014 } & Hair & $54.7(100)$ & $170.1(100)$ \\
\cline { 2 - 4 } & Urine & $15.0(100)$ & $869.5(100)$ \\
\hline
\end{tabular}




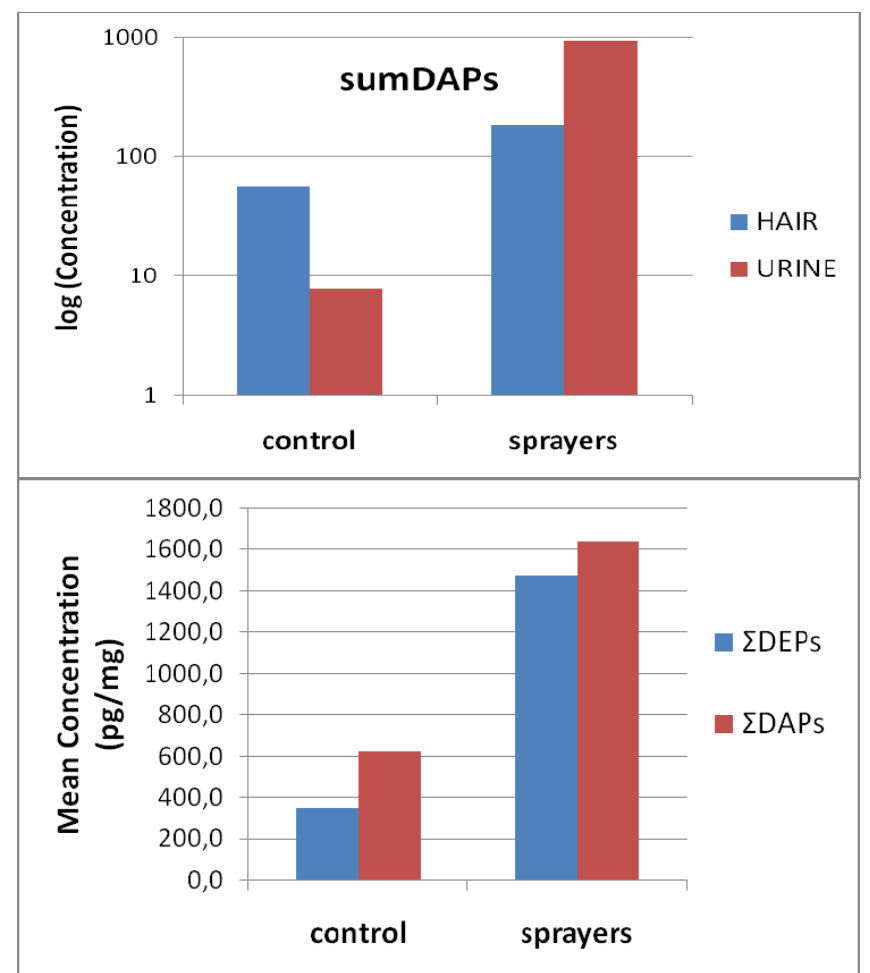

Fig. 2. Top: Comparison of sumDAPs levels in hair and urine samples of control and sprayers groups (Kokkinaki et al., 2014). Bottom: SumDEPs and sumDAPs median values $(\mathrm{pg} / \mathrm{mg})$ in head hair samples. Comparison between the control and sprayers groups (Tsatsakis et al., 2010)

sumDMPs was positively associated with birth weight, although rural residents were not significantly differentiated from the urban population. Notably a seasonal variation in the levels of DAPs in AF was observed (Fig. 3) and it represents the use of certain OPs used in cultivations at specific periods of the year. High levels of DMPs were detected during autumn of 2006 and 2007 and spring 2008. DMPs are the metabolites of malathion and dimethoate which are used for the systematic spraying of common agricultural products in Crete like apples, grapevines, vegetables and olive oil trees. DEPs are metabolites of chlorpyrifos and diazinon and showed high levels during winter 2006-2007 and autumn 2007 due to the widespread use of diazinon in vineyards and fruits.

Meconium starts to be produced after 16 weeks of gestation and it is not excreted until birth.
Consequently, pollutants that fetus is exposed to through his mother, are accumulated and it can be considered as a suitable matrix for the assessment of fetal exposure to OPs (Tsatsakis et al., 2009a). Samples from mothers in Greece were analyzed for DMP, DEP, DMTP, DETP and DEDTP and the positive samples ranged from $57.9 \%$ (DEDTP) to $92.1 \%$ (DMP). The range concentrations for each metabolite were 10.64-739.45 $\mathrm{ng} / \mathrm{g}$ (DMP), 1.50-79.14 (DEP), 8.54-662.16 (DMTP), 1.25-19.04 (DETP) and 0.5-8.04 (DEDTP). The pesticides burden in meconium as presented in this study was greater than reported in AF and urine elsewhere (Kokkinaki et al., 2014; Koureas et al., 2014).

There are many studies in literature about the impact of pesticide exposure on fetuses (Androutsopoulos et al., 2013; Eskenazi et al., 2010; Hernandez et al., 2013). Effects on brain 


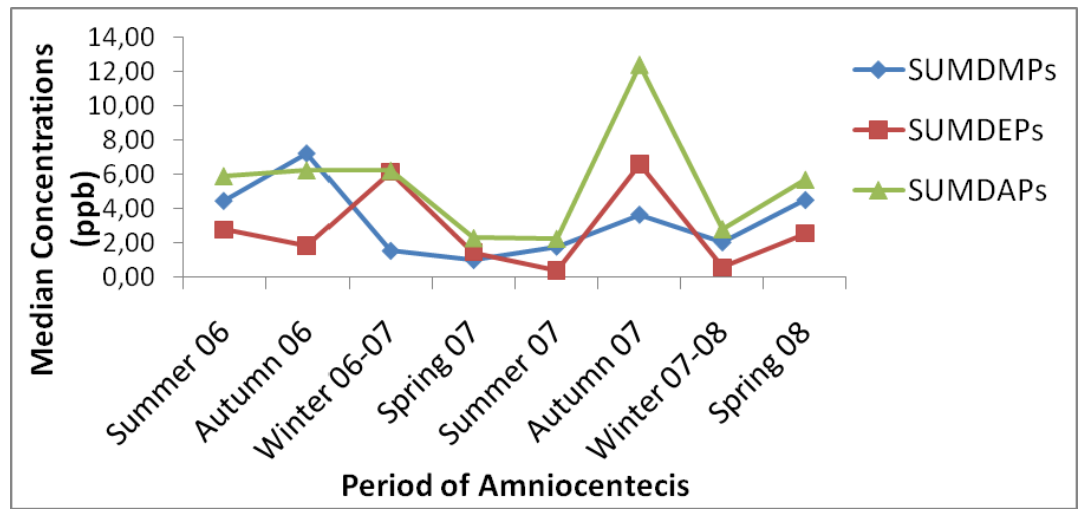

Fig. 3. Seasonal variation of DAP metabolites measured in amniotic fluid from mothers in Greece (Koutroulakis et al., 2014)

development(Dametal., 2003; Slotkin and Seidler, 2007) and interactions with the endocrine system (Fowler et al., 2007) are reported. Correlations between DAPs in meconium and adverse birth outcomes came up also from this study (Tsatsakis et al., 2009a). It seems that exposure to OPs during pregnancy is related with complications during pregnancy, gestational week of delivery, congenital abnormalities and birth weight.

In a review study (Kavvalakis and Tsatsakis, 2012) a global overview of the biomonitoring data of OPs from 1990 to 2011 was presented. The greater burden of agricultural workers has been confirmed in both urine and hair samples. The detected levels of DAPs in human urine in worldwide scale ranged from 18 to $830 \mathrm{ng} / \mathrm{ml}$ for the general population and from 29 to $1370 \mathrm{ng} / \mathrm{ml}$ for the exposed groups. The ranged concentrations for DAPs in AF and meconium were 0.3$2.8 \mathrm{ng} / \mathrm{ml}$ and $0.5-16,000 \mathrm{ng} / \mathrm{ml}$, respectively. Levels in hair from the general population were between 40.0 and $165.0 \mathrm{pg} / \mathrm{mg}$ and between 181.7 and $812.9 \mathrm{pg} / \mathrm{mg}$ for the occupationally exposed group. Comparison among countries and continents would give interesting results since the pesticides used and the cultivations are varying. The general trend between Europe and America is that general population is less exposed to pesticides relatively to pesticide applicators for both continentals (Fig. 4). However, it seems that exposure to pesticides is greater for Europeans than Americans.

\section{Human monitoring of OCs exposure}

DDT is a very effective organochlorine insecticide, introduced in market in 1944, during World War II and banned in the 1970s in the entire developed world. When DDT enters human body it is slowly metabolized to 1,1-dichloro-2,2-bis-(4-chlorophenyl)ethylene (DDE) and 1,1-dichloro-2,2-bis(4-chlorophenyl) ethane (DDD). The parent compound and its metabolites are extremely lipophilic compounds which are stored in the fatty tissues. Lindane is the $\gamma$-isomer of the hexachlorocyclohexane $(\mathrm{HCH})$ which is an excessively used insecticide because it is very cheap and effective. It is also a persistent compound, slowly metabolized and stored in the fatty tissues. Possible target organs for lindane are the central nervous system, immune system, liver, kidneys, pancreas and testes (Betoulle et al., 2000; Johri et al., 2008; Saradha et al., 2008). Long term exposure to DDT has a potential impact on breast cancer, diabetes, decreased semen quality, spontaneous abortion 


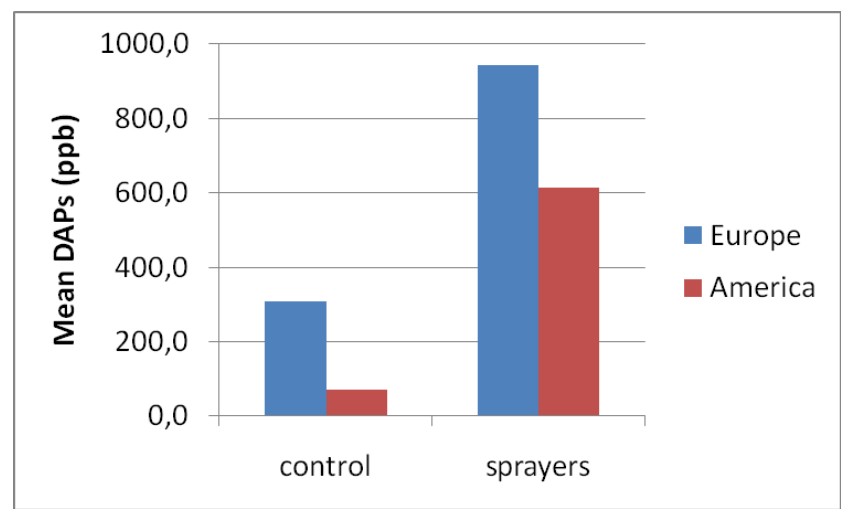

Fig. 4. Intercontinental comparison of the biomonitoring data for DAPs in urine from exposed and general population (Kavvalakis and Tsatsakis, 2012)

and impaired neurodevelopment in children (Eskenazi et al., 2010). It is still a controversial issue whether low exposure to OCs can be related with impairment of cognitive function leading to dementia and Alzheimer disease (Singh et al., 2013; Medehouenou et al., 2014; Kim et al., 2015; Richardson et al., 2014).

Hair analysis gives information about chronic exposure to pollutants and therefore it is the most appropriate matrix for the assessment of human exposure to persistent organic pollutants (POPs) like organochlorine pesticides (Tsatsakis et al., 2008a). Hair samples of 222 rural residents in Helia Peloponnesus (Greece) were collected and analyzed for DDTs (opDDE, ppDDE, opDDD, ppDDD, opDDT, and ppDDT) and HCHs $(\alpha-\mathrm{HCH}$, hexachlorobenzene [HCB], lindane $[\mathrm{HCHs}])$. About $32.4 \%$ of the samples were positive for at least one DDT isomer and metabolite and the percentage detection frequencies ranged from $2.7 \%$ (opDDE) to $13.5 \%$ (ppDDE) (Table 2). Approximately $50.5 \%$ of the samples were burdened with at least one $\mathrm{HCH}$ isomer. The detection rates for lindane, $\alpha-\mathrm{HCH}$ and $\mathrm{HCB}$ were $33.2 \%, 30.6 \%$ and $26.1 \%$ respectively. The sum of $\mathrm{HCHs}$ (mean 189.2 and median $117.8 \mathrm{pg} / \mathrm{mg}$ ) was higher relatively to the sum of DDTs (mean 56.4 and median $9.4 \mathrm{pg} / \mathrm{mg}$ ). Statistical treatment of data revealed no significant association between exposure to OCs and gender or age.

The analysis of hair samples for DDTs (op and pp isomers of DDE, DDD and DDT) from children living in rural and urban regions gave statistically significant differentiations (Tzatzarakis et al., 2014). Two rural regions and one urban were examined (Crete, Greece) and it was concluded that rural residents had greater exposure $(\mathrm{p}=0.001)$ and more positive samples $(p<0.05)$ relatively to townspeople. These correlations were significant for urban/ rural classification and per region comparison. More specifically, median levels of sumDDTs in urban, rural $A$ and rural $B$ regions were $4.7 \mathrm{pg} / \mathrm{mg}, 11.7 \mathrm{pg} / \mathrm{mg}$ and $4.6 \mathrm{pg} / \mathrm{mg}$ respectively. In rural region $\mathrm{A}$ there were $100 \%$ positive samples for sumDDTs, $96.6 \%$ in rural B and $80.0 \%$ in urban. Although DDT is a banned insecticide, it is still detected in human body possibly due to its extensive use in the past and its bioaccumulation in living organisms.

Different types of cultivations and agricultural occupation can result in different exposures to pesticides amongst agricultural workers. Thus, three population groups 
Table 2. Median concentrations of total HCHs and DDTs in hair samples (pg/mg) and serum (ng/ml) from Greek population

\begin{tabular}{|l|l|l|c|c|}
\hline \multicolumn{1}{|c|}{ Study } & \multicolumn{1}{|c|}{ N, population } & $\begin{array}{c}\text { Biological } \\
\text { Matrix }\end{array}$ & $\begin{array}{c}\text { sumHCHs } \\
\text { (\% positive } \\
\text { samples) }\end{array}$ & $\begin{array}{c}\text { sumDDTs } \\
(\% \text { positive } \\
\text { samples })\end{array}$ \\
\hline Tsatsakis et al., 2008a & $\begin{array}{l}\text { 222, rural residents in Helia } \\
\text { Peloponnesus }\end{array}$ & Head Hair & $117.8(50.5)$ & $9.4(32.4)$ \\
\hline Tsatsakis et al., 2008b & $\begin{array}{l}\text { 211, agricultural workers in Messara } \\
\text { and Sitia in Crete }\end{array}$ & Head Hair & $79.6(28.1)$ & $37.3(67.3)$ \\
\hline Tzatzarakis et al., 2014 & $\begin{array}{l}72, \text { urban and rural residents from } \\
\text { Crete }\end{array}$ & Head Hair & - & $4.6(94.4)$ \\
\hline Koureas et al., 2016 & 103 , general population from Larissa & Serum & $0.13(67.96)$ & $1.25(99.03)$ \\
\hline
\end{tabular}

including greenhouse workers, animal breeders and workers in open cultivations were used for the comparison between body burden and type of occupational exposure to pesticides (Tsatsakis et al., 2008b). The study population (211 individuals) was exposed to OPs (diazon, fenthion, methyl parathion and malathion) and OCs $(\mathrm{HCH}, \mathrm{DDT})$. Population was burdened with higher levels of $\mathrm{HCHs}$ compared to DDTs. Greenhouse workers were exposed to $95.0 \mathrm{pg} / \mathrm{mg} \mathrm{HCHs}$ and $8.9 \mathrm{pg} / \mathrm{mg}$ DDTs, animal breeders $38.2 \mathrm{pg} / \mathrm{mg} \mathrm{HCHs}$ and $3.3 \mathrm{pg} / \mathrm{mg}$ DDTs, open cultivation workers $24.1 \mathrm{pg} / \mathrm{mg}$ $\mathrm{HCHs}$ and $5.2 \mathrm{pg} / \mathrm{mg}$ DDTs. Biomonitoring data showed that the DDTs burden is similar in the three groups $(\mathrm{p}=0.528)$, but $\mathrm{HCHs}$ burden is significantly higher and especially for greenhouse workers $(p=0.009)$. This particular research comprises a part of another study (Tsatsakis etal.,2009b) in which 533 hairsamples from Cretan population (463 rural residents and 70 urban residents) were analyzed to assess exposure to OCs and OPs. The detected levels of sumHCHs were significantly differentiated between rural (median, $90.7 \mathrm{pg} / \mathrm{mg}$ ) and urban residents (median, $41.6 \mathrm{pg} / \mathrm{mg}$ ). On the other hand, no difference was documented for sumDDTs between the two population groups (rural, $38.4 \mathrm{pg} / \mathrm{mg}$ and urban, $32.6 \mathrm{pg} / \mathrm{mg}$ ).
Apart from hair analysis, serum can also be used in biomonitoring of past exposure to pesticides (Koureas et al., 2016). Serum samples from 103 volunteers from Central Greece were analyzed for a-chlordane, c-chlordane, DDD, DDT, DDE and hexachlorbenzene (HCB), heptachlor epoxide and heptachlor. Almost all examined individuals were positive for ppDDE (99.03\%). The other compounds were detected at lower frequencies ranging between $0.97 \%$ (heptachlor epoxide) and $67.96 \%$ (HCB). The median concentrations for the most commonly detected compounds were $1.25 \mathrm{ng} / \mathrm{ml}$ (ppDDE) and $0.13 \mathrm{ng} / \mathrm{ml}$ (HCB). Statistical treatment of data showed no correlations between exposure and gender or lifestyle habits. However, elderly population and individuals with primary or no education had higher exposure to OCs ( $\mathrm{p}$ range, 0.002-0.015) and HCB (p range, <0.001-0.043). The reported exposures to OCs in this study possibly reflect past exposures to DDT mainly though diet and environment.

\section{Adverse health effects linked \\ to pesticide exposure}

Several review studies have been published presenting the adverse health effects of pesticides exposure (Androutsopoulos et al., 2013; Koureas et al., 2012). The association between prenatal 
pesticide exposure and potential adverse birth outcomes is a point of interest for many researchers. Three large cohort studies, the CHAMACOS cohort (Eskenazi et al., 2004), the CCCEH cohort (Perera et al., 2003; Whyatt et al., 2004) and the Mount Sinai cohort (Berkowitz et al., 2004; Wolff et al., 2007) have investigated the associations between maternal exposure to pesticides during pregnancy and effects on gestation and newborns. The results showed that exposure to OPs is negatively associated with gestation duration (Eskenazi et al., 2004), birth weight and birth length (Whyatt et al., 2004). Prenatal and postnatal exposure to OPs was associated with pervasive development disorder, decreased cognitive abilities (Eskenazi et al., 2007) and attention problems not only in newborns but in 5-year old children (Marks et al., 2010). Rauh and co-authors (2006) confirmed these findings and also proposed that chlorpyrifos is significantly associated with both mental and motor delays and hyperactivity disorder.

Pesticide exposure in male adults is significantly associated with sperm DNA damage and fragmentation (Ji et al., 2011; Meeker et al., 2008; Sanchez-Pena et al., 2004). A significant decrease in sperm concentration, sperm motility, sperm count and sperm volume is reported among individuals with high OP exposure (Perry et al., 2007; Recio-Vega et al., 2008; Yucra et al., 2008; Ji et al., 2011; Xia et al., 2008).

Several studies correlate pesticide exposures with hormone disorders appeared in occupationally and non-occupationally exposed males. Thyroid hormones measurements in serum, including levels of thyrotropin (TSH), total thyroxine (T3) and triiodothyronine (T4), showed significant associations with urinary DAPs (Lacasana et al., 2010a, b; Meeker et al., 2006). Serum levels of Follicle stimulating hormone (FSH), Luteinizing hormone (LH), prolactin, testosterone, inhibin $\mathrm{B}$ and estradiol were determined in a cross - sectional study among floriculturists in Mexico (Blanco-Munoz et al., 2010). A negative association was found between inhibin B and four DAP metabolites. DEP was inversely correlated with FSH and DETP was associated with lower LH levels.

Long term exposure to OCs and OPs has been associated with hepatitis, cardiovascular disease, prostate cancer and thyroid function by many studies (Lacasana et al., 2010a, b; Tsatsakis et al., 2009b, 2011). Organochlorine pesticides are suspected to cause cancer in humans because they are shown to induce DNA damage in human lymphocyte cultures and impair the structural integrity of c-myc and TP53 genes (Mladinic et al., 2012). Vakonaki and co-authors (2013) emphasized on the relation between pesticide exposure and dysregulated cancer-related genes and the interactions of pesticides upon oncogenic proteins and tumor suppressor proteins. OCs such as pp-DDT and pp-DDE could play a part in the pathogenesis of exocrine pancreatic cancer via modulation of $\mathrm{K}$-ras activation, although the exact mechanism in human populations remains unclear (Porta et al., 1999). Occupational exposure to pesticides increases the incidence of non-Hodgins lymphoma especially during the high pesticide use period (Roulland et al., 2004). Occupational risk of pesticide exposure is an important determinant of mutation development at key-genes involved in cellular proliferation and cell cycle control. The exact mechanisms that underlie the progression of a "healthy" to an "oncogenic" genotype in human populations exposed to pesticides remain unclear, mainly due to the plethora of chemical used, the main route and severity of exposure, as well as the complexity of genomic information of each population.

\section{Conclusions}

In summary, human is either occupationally, dietary or environmentally exposed to pesticides. 
Occupational exposure refers to agricultural workers and pesticide applicators. Occupationally exposed to pesticides populations have a greater body burden than general population. The use of personal protective measures and use of full body coveralls are mandatory and offer an effective protection against pesticide exposures. To ensure the safety of consumers and agricultural workers, there is need for the continuous education and training of those involved in the production and distribution of products, for the safety of their work, the potential risks and the recent advances in crop protection. Environmental exposure includes exposure via food and water consumption and air breathing polluted with pesticides residues due to their extensive use. The presence of pesticide residues in foodstuffs is worrying although the detected levels in products from Greek market are low.

Biomonitoring using various biological samples enables the assessment of the type of exposure (acute, systematic, severe, chronic) and the association of this exposure with adverse health impacts. Several studies have measured pesticides or their metabolites levels in urine and blood samples, amniotic fluid, meconium and hair from general and occupationally exposed populations. OCs are lipophilic compounds which are accumulated in human body. Thus, hair analysis is a powerful tool to assess chronic exposure to pesticides and biomonitoring data can be used to estimate the time of exposure to a certain pesticide. Long term exposure to OCs and OPs has been associated with hepatitis, cardiovascular disease, cancer and thyroid function by many studies. Prenatal exposure is associated with adverse birth outcomes, short gestation duration, birth weight and birth length. Adverse health problems appeared in childhood may be a result from maternal exposure during pregnancy. Pervasive development disorder, decreased cognitive abilities, mental and motor delays, hyperactivity disorder and attentional problems in 5-year old children are linked to prenatal exposure to certain pesticides. In male adults, decreased sex-hormone levels, sperm quality and sperm DNA damage are also associated with pesticide exposure. The above data and results of the studies conducted so far, do not minimize the need for new biomonitoring studies but emphasize the need for more action to secure the public health.

\section{References}

Amanvermez R., Baydin A., Yardan T., Basol N., Gunay M. (2010) Emerging laboratory abnormalities in suicidal patients with acute organophosphate poisoning. Turk. J. Biochem., 35: 29-34

Androutsopoulos V.P., Hernandez A.F., Liesivuori J., Tsatsakis A.M. (2013) A mechanistic overview of health associated effects of low levels of organochlorine and organophosphorous pesticides. Toxicology, 307: 89-94. http://doi.org/10.1016/j.tox.2012.09.011

Barr D.B., Bravo R., Weerasekera G., Caltabiano L.M., Whitehead R.D., Olsson A.O., Caudill S.A., Schober S.E., Pirkle J.L., Sampson E.J., Jackson R.J., Needham L.L. (2004) Concentrations of dialkyl phosphate metabolites of organophosphorus pesticides in the US population. Environmental Health Perspectives, 112: 186-200

Barr D.B., Needham L.L. (2002) Analytical methods for biological monitoring of exposure to pesticides: a review. J. Chromatogr. B, 778: 5-29

Berkowitz G.S., Wetmur J.G., Birman-Deych E., Obel J., Lapinski R.H., Goldbold J.H., Holzman I.R., Wolff M.S. (2004) In utero pesticides exposure, maternal paraoxonase activity, and head circumference. Environmental Health Perspectives, 112: 388-391 
Betoulle S., Duchiron C., Deschaux P. (2000) Lindane increases in vitro respiratory burst activity and intra-cellular calcium levels in rainbow trout (Oncorhynchus mykiss) head kidney phagocytes. Aquat. Toxicol., 48: 211-221

Blanco-Munoz J., Morales M.M., Lacasana M., Aguilar-Gardun C., Bassol S., Cebrian M.E. (2010) Exposure to organophosphate pesticides and male hormone profile in floriculturist of the state of Morelos, Mexico. Human Reprod., 25: 1787-1795

Bradman A., Whitaker D., Quiros L., Castorina R., Henn B.C., Nishioka M., Morgan J., Barr D.B., Harnly M., Brisbin J.A., Sheldon L.S., McKone T.E., Eskenazi B. (2007) Pesticides and their metabolites in the homes and urine of farmworker children living in the Salinas Valley, CA. Journal of Exposure Science and Environmental Epidemiology, 17: 331-349

Cakir S., Sarikaya R. (2005) Genotoxicity testing of some organophosphate insecticides in the Drosophila wing spot test. Food and Chemical Toxicology, 43: 443-450

Casals-Casas C., Desvergne B. (2011) Endocrine disruptors: from endocrine to metabolic disruption. Annu. Rev. Physiol., 73: 135-162

$C D C$ (2009) Centers for Disease Control and Prevention, Fourth National Report on Human Exposure to Environmental Chemicals. http://www.cdc.gov/exposurereport/pdf/FourthReport.pdf (Accessed 24.01.17)

Dam K., Seidler F.J., Slotkin T.A. (2003) Transcriptional biomarkers distinguish between vulnerable periods for developmental neurotoxicity of chlorpyrifos: implications for toxicogenomics. Brain Res. Bull., 59: 261-265

Dolapsakis G., Vlachonikolis I.G., Varveris C., Tsatsakis A.M. (2001) Mammographic findings and occupational exposure to pesticides currently in use on Crete. European Journal of Cancer, 37: $1531-1536$

EFSA (2008) Annual Report on Pesticide Residues according to Article 32 of Regulation (EC) No 396/2005. https://www.efsa.europa.eu/en/efsajournal/pub/1646 (accessed 27.01.17)

Eskenazi B., Huen K., Marks A., Harley K.G., Bradman A., Barr D.B., Holland N. (2010) PON1 and neurodevelopment in children from the CHAMACOS study exposed to organophosphate pesticides in utero. Environ. Health Perspect., 118: 1775-1781

Eskenazi B., Marks A.R., Bradman A., Harley K., Barr D.B., Johnson C., Morga N., Jewell N.P. (2007) Organophosphate pesticide exposure and neurodevelopment in young Mexican-American children. Environ. Health Perspect., 115: 792-798

Eskenazi B., Harley K., Bradman A., Weltzien E., Jewell N.P., Barr D.B., Furlong C.E., Holland N.T. (2004) Association of in utero organophosphate pesticide exposure and fetal growth and length of gestation in an agricultural population. Environ. Health Perspect., 112: 1116-1124

Everett C.J., Matheson E.M. (2010) Biomarkers of pesticide exposure and diabetes in the 19992004 National Health and Nutrition Examination Survey. Environ. Int., 36 (4): 398-401

Fowler P.A., Abramovich D.R., Haites N.E., Cash P., Groome N.P., Al-Qahtani A., Murray T.J., Lea R.G. (2007) Human fetal testis Leydig cell disruption by exposure to the pesticide dieldrin at low concentrations. Hum. Reprod., 22: 2919-2927

Giordano G., Afsharinejad Z., Guizzetti M., Vitalone A., Kavanagh T.J., Costa L.G. (2007) Organophosphorus insecticides chlorpyrifos and diazinon and oxidative stress in neuronal cells in a genetic model of glutathione deficiency. Toxicology and Applied Pharmacology, 219: 181-189 
Hernandez A.F., Parron T., Tsatsakis A.M., Requena M., Alarcon R., Lopez-Guarnido O. (2013) Toxic effects of pesticide mixtures at a molecular level: their relevance to human health. Toxicology, 307: $136-145$

Ji G., Xia Y., Gu A., Shi X., Long Y., Song L., Wang S., Wang X. (2011) Effects of non-occupational environmental exposure to pyrethroids on semen quality and sperm DNA integrity in Chinese men. Reprod. Toxicol., 31: 171-176

Johri A., Dhawan A., Singh R.L., Parmar D. (2008) Persistence in alterations in the ontogeny of cerebral and hepatic cytochrome P450s following prenatal exposure to low doses of lindane. Toxicol. Sci., 101: 331-340

Kang H.G., Jeong S.H., Cho J.H., Kim D.G., Park J.M., Cho M.H. (2004) Chlropyrifosmethyl shows anti-androgenic activity without estrogenic activity in rats. Toxicology, 199: 219-230

Kavvalakis M.P., Tsatsakis A.M. (2012) The atlas of dialkylphosphates; assessment of cumulative human organophosphorus pesticides' exposure. Forensic Science International, 218(1-3): 111-122. http://doi.org/10.1016/j.forsciint.2011.10.019

Kim K.S., Lee Y.M., Lee H.W., Jacobs D.R., Lee D.H. (2015) Associations between organochlorine pesticides and cognition in U.S. elders: National Health and Nutrition Examination Survey 1999-2002. Environment International, 75: 87-92. http://doi.org/10.1016/j.envint.2014.11.003

Kokkinaki A., Kokkinakis M., Kavvalakis M.P., Tzatzarakis M.N., Alegakis A.K., Maravgakis G., Babatsikou F., Fragkiadakis G.A., Tsatsakis A.M. (2014) Biomonitoring of dialkylphosphate metabolites (DAPs) in urine and hair samples of sprayers and rural residents of Crete, Greece. Environmental Research, 134: 181-187. http://doi.org/10.1016/j.envres.2014.07.012

Koureas M., Karagkouni F., Rakitskii V., Hadjichristodoulou C., Tsatsakis A., Tsakalof A. (2016) Serum levels of organochlorine pesticides in the general population of Thessaly, Greece, determined by HS-SPME GC-MS method. Environmental Research, 148: 318-321. http://doi.org/10.1016/j. envres.2016.04.015

Koureas M., Tsakalof A., Tzatzarakis M., Vakonaki E., Tsatsakis A., Hadjichristodoulou C. (2014) Biomonitoring of organophosphate exposure of pesticide sprayers and comparison of exposure levels with other population groups in Thessaly (Greece). Occupational and Environmental Medicine, 71(2): 126-133. http://doi.org/10.1136/oemed-2013-101490

Koureas M., Tsakalof A., Tsatsakis A., Hadjichristodoulou C. (2012) Systematic review of biomonitoring studies to determine the association between exposure to organophosphorus and pyrethroid insecticides and human health outcomes. Toxicology Letters, 210(2): 155-168. http://doi. org/10.1016/j.toxlet.2011.10.007

Koutroulakis D., Sifakis S., Tzatzarakis M.N., Alegakis A.K., Theodoropoulou E., Kavvalakis M.P., Kappou D., Tsatsakis A.M. (2014) Dialkyl phosphates in amniotic fluid as a biomarker of fetal exposure to organophosphates in Crete, Greece; association with fetal growth. Reprod. Toxicol., 46: 98-105. doi:10.1016/j.reprotox.2014.03.010

Lacasana M., Lopez-Flores I., Rodriguez-Barranco M., Aguilar-Garduno C., Blanco- Munoz J., Perez-Mendez O., Gamboa R., Bassol S., Cebrian M.E. (2010a) Association between organophosphate pesticides exposure and thyroid hormones in floriculture workers. Toxicol. Appl. Pharmacol., 243: $19-26$ 
Lacasana M., Lopez-Flores I., Rodriguez-Barranco M., Aguilar-Garduno C., Blanco-Munoz J., Perez-Mendez O., Gamboa R., Gonzalez-Alzaga B., Bassol S., Cebrian M.E. (2010b) Interaction between organophosphate pesticide exposure and PON1 activity on thyroid function. Toxicol. Appl. Pharmacol., 249: 16-24

Lee D.H., Steffes M.W., Sjödin A., Jones R.S., Needham L.L., Jacobs Jr. D.R. (2011) Low dose organochlorine pesticides and polychlorinated biphenyls predict obesity, dyslipidemia, and insulin resistance among people free of diabetes. PLoS ONE, 6 (1): e15977

Margariti M.G., Tsakalof A.K., Tsatsakis A.M. (2007) Analytical methods of biological monitoring for exposure to pesticides: recent update. Ther. Drug Monit., 29: 150-163

Margariti M.G., Tsatsakis A.M. (2009) Analysis of dialkyl phosphate metabolites in hair using gas chromatography-mass spectrometry: a biomarker of chronic exposure to organophosphate pesticides. Biomarkers: Biochemical Indicators of Exposure, Response, and Susceptibility to Chemicals, 14(November): 137-147. http://doi.org/10.1080/13547500902792912

Marks A.R., Harley K., Bradman A., Kogut K., Barr D.B., Johnson C., Calderon N., Eskenazi B. (2010) Organophosphate pesticide exposure and attention in young Mexican-American children: the CHAMACOS study. Environ. Health Perspect., 118: 1768-1774

Medehouenou T.C.M., Ayotte P., Carmichael P.H., Kröger E., Verreault R., Lindsay J., Dewailly É., Tyas S.L., Bureau A., Laurin D. (2014) Plasma polychlorinated biphenyl and organochlorine pesticide concentrations in dementia: The Canadian study of health and aging. Environment International, 69: 141-147. http://doi.org/10.1016/j.envint.2014.04.016

Meeker J.D., Barr D.B., Hauser R. (2006) Thyroid hormones in relation to urinary metabolites of non-persistent insecticides in men of reproductive age. Reprod. Toxicol., 22: 437-442

Meeker J.D., Barr D.B., Hauser R. (2008) Human semen quality and sperm DNA damage in relation to urinary metabolites of pyrethroid insecticides. Human Reprod., 23: 1932-1940

Mladinic M., Zeljezic D., Shaposhnikov S.A., Collins A.R. (2012) The use of FISH- comet to detect c-myc and Tp53 damage in extended-term lymphocyte cultures treated with terbuthylazine and carbofuran. Toxicol. Lett., 211: 62-69

Perera F.P., Rauh V., Tsai W.Y., Kinney P., Camann D., Barr D., Bernert T., Garfinkel R., Tu Y.H., Diaz D., Dietrich J., Whyatt R.M. (2003) Effects of transplacen- tal exposure to environmental pollutants on birth outcomes in a multiethnic population. Environ. Health Perspect., 111: 201-205

Perry M.J., Venners S.A., Barr D.B., Xu X. (2007) Environmental pyrethroid and organophosphorus insecticide exposures and sperm concentration. Reprod. Toxicol., 23: 113-118

Porta M., Malats N., Jariod M., Grimalt J.O., Rifa J., Carrato A., Guarner L., Salas A., SantiagoSilva M., Corominas J.M., Andreu M., Real F.X. (1999) Serum concentration of organochlorine compounds and K-ras mutations in exocrine pancreatic cancer. PANKRAS II study group. Lancet, 354: $2125-2129$

Rauh V.A., Garfinkel R., Perera F.P., Andrews H.F., Hoepner L., Barr D.B., Whitehead R., Tang D., Whyatt R.W. (2006) Impact of prenatal chlorpyrifos exposure on neu- rodevelopment in the first 3 years of life among inner-city children. Pediatrics, 118: e1845-e1859

Recio-Vega R., Ocampo-Gomez G., Borja-Aburto V.H., Moran-Martinez J., Cebrian- Garcia M.E. (2008) Organophosphorus pesticide exposure decreases sperm quality: association between sperm parameters and urinary pesticide levels. J. Appl. Toxicol., 28: 674-680 
Richardson J.R., Roy A., Shalat S.L., Von Stein R.T., Hossain M.M., Buckley B., Gearing M., Levey A.I., German D.C. (2014) Elevated serum pesticide levels and risk for Alzheimer disease. JAMA Neurol., 71(3): 284-290. http://doi.org/10.1001/jamaneurol.2013.6030.Elevated

Rothlein J., Rohlman D., Lasarev M., Phillips J., Muniz J., McCauley L. (2006) Organophosphate pesticide exposure and neurobehavioral performance in agricultural and nonagricultural Hispanic workers. Environmental Health Perspectives, 114: 691-696

Roulland S., Lebailly P., Lecluse Y., Briand M., Pottier D., Gauduchon P. (2004) Characterization of the $\mathrm{t}(14 ; 18)$ BCL2-IGH translocation in farmers occupationally exposed to pesticides. Cancer Res., 64: 2264-2269

Sanchez-Pena L.C., Reyes B.E., Lopez-Carrillo L., Recio R., Moran-Martinez J., Cebrian M.E., Quintanilla-Vega B. (2004) Organophosphorous pesticide expo- sure alters sperm chromatin structure in Mexican agricultural workers. Toxicol. Appl. Pharmacol., 196: 108-113

Sarabia L., Maurer I., Bustos-Obregon E. (2009) Melatonin prevents damage elicited by the organophosphorous pesticide diazinon on the mouse testis. Ecotoxicology and Environmental Safety, 72: 938-942

Saradha B., Vaithinathan S., Mathur P.P. (2008) Lindane alters the levels of HSP70 and clusterin in adult rat testis. Toxicology, 243: 116-123

Singh N., Chhillar N., Banerjee B., Bala K., Basu M., Mustafa M. (2013) Organochlorine pesticide levels and risk of Alzheimer's disease in north Indian population. Human \& Experimental Toxicology, 32(1): 24-30. http://doi.org/10.1177/0960327112456315

Slotkin T.A., Seidler F.J. (2007) Comparative developmental neurotoxicity of organophosphates in vivo: transcriptional responses of pathways for brain cell development, cell signaling, cytotoxicity and neurotransmitter systems. Brain Res. Bull., 72: 232-274

Thompson B., Coronado G.D., Vigoren E.M., Griffith W.C., Fenske R.A., Kissel J.C., Shirai J.H., Faustman E.M. (2008) Para Ninos Saludables: A community intervention trial to reduce organophosphate pesticide exposure in children of farmworkers. Environmental Health Perspectives, 116: 687-694

Tsakiris I.N., Kokkinakis E., Dumanov J.M., Tzatzarakis M.N., Flouris A.D., Vlachou M., Tsatsakis A.M. (2013) Comparative evaluation of xenobiotics in human and dietary milk: Persistent organic pollutants and mycotoxins. Cellular and Molecular Biology, 59(1): 58-66. http://doi.org/10.1170/ T947

Tsakiris I.N., Goumenou M., Tzatzarakis M.N., Alegakis A.K., Tsitsimpikou C., Ozcagli E., Vynias D., Tsatsakis A.M. (2015) Risk assessment for children exposed to DDT residues in various milk types from the Greek market. Food and Chemical Toxicology, 75: 156-165. http://doi.org/10.1016/j. fct.2014.11.012

Tsatsakis A.M., Tsakiris I.N., Tzatzarakis M.N., Agourakis Z.B., Tutudaki M., Alegakis A.K. (2003) Three-year study of fenthion and dimethoate pesticides in olive oil from organic and conventional cultivation. Food Additives and Contaminants, 20(6): 553-559. http://doi. org/10.1080/0265203031000070786

Tsatsakis A.M., Tzatzarakis M.N., Tutudaki M., Babatsikou F., Alegakis A.K., Koutis C. (2008a) Assessment of levels of organochlorine pesticides and their metabolites in the hair of a Greek rural human population. Human \& Experimental Toxicology, 27(12): 933-940. http://doi. org/10.1177/0960327108102047 
Tsatsakis A.M., Tzatzarakis M.N., Tutudaki M. (2008b) Pesticide levels in head hair samples of Cretan population as an indicator of present and past exposure. Forensic Science International, 176(1): 67-71. http://doi.org/10.1016/j.forsciint.2007.07.017

Tsatsakis A.M., Tzatzarakis M.N., Koutroulakis D., Toutoudaki M., Sifakis S. (2009a) Dialkyl phosphates in meconium as a biomarker of prenatal exposure to organophosphate pesticides: a study on pregnant women of rural areas in Crete, Greece. Xenobiotica; the Fate of Foreign Compounds in Biological Systems, 39(5): 364-373. http://doi.org/10.1080/00498250902745090

Tsatsakis A.M., Zafiropoulos A., Tzatzarakis M.N., Tzanakakis G.N., Kafatos A. (2009b) Relation of PON1 and CYP1A1 genetic polymorphisms to clinical findings in a cross-sectional study of a Greek rural population professionally exposed to pesticides. Toxicology Letters, 186(1): 66-72. http://doi. org/10.1016/j.toxlet.2008.10.018

Tsatsakis A.M., Barbounis M.G., Kavalakis M., Kokkinakis M., Terzi I., Tzatzarakis M.N. (2010) Determination of dialkyl phosphates in human hair for the biomonitoring of exposure to organophosphate pesticides. Journal of Chromatography B: Analytical Technologies in the Biomedical and Life Sciences, 878(17-18): 1246-1252. http://doi.org/10.1016/j.jchromb.2010.02.021

Tsatsakis A.M., Androutsopoulos V.P., Zafiropoulos A., Babatsikou F., Alegakis T., Dialyna I., Tzatzarakis M., Koutis C. (2011) Associations of xenobiotic-metabolizing enzyme genotypes PON1Q192R, PON1L55M and CYP1A1*2A MspI with pathological symptoms of a rural population in south Greece. Xenobiotica, 41: 914-925. doi:10.3109/00498254.2011.590545.

Tsatsakis A., Tutudaki M., Tzatzarakis M., Dawson A., Mohamed F., Christaki M., Alegkakis A. (2012) Is hair analysis for dialkyl phosphate metabolites a suitable biomarker for assessing past acute exposure to organophosphate pesticides? Hum. Exp. Toxicol., 31: 266-273. doi:10.1177/0960327111403171

Tyler C.R., Beresford N., Van Der Woning M., Sumpter J.P., Thorpe K. (2000) Metabolism and environmental degradation of pyrethroid insecticides produce compounds with endocrine activities. Environ. Toxicol. Chem., 19: 801-809

Tzatzarakis M.N., Barbounis E.G., Kavvalakis M.P., Vakonaki E., Renieri E., Vardavas A.I., Tsatsakis A.M. (2014) Rapid method for the simultaneous determination of DDTs and PCBs in hair of children by headspace solid phase microextraction and gas chromatography-mass spectrometry (HSSPME/GC-MS). Drug Testing and Analysis, 6(S1): 85-92. http://doi.org/10.1002/dta.1631

US EPA (2013) United States Environmental Protection Agency. Recognition and Management of pesticide poisonings. $6^{\text {th }}$ Edition. Chapter 5. https://www.epa.gov/sites/production/files/documents/ rmpp_6thed_ch5_organophosphates.pdf (Accessed 24.01.17)

Vakonaki E., Androutsopoulos V.P., Liesivuori J., Tsatsakis A.M., Spandidos D.A. (2013) Pesticides and oncogenic modulation. Toxicology, 307: 42-45. http://doi.org/10.1016/j.tox.2013.01.008

Whyatt R.M., Rauh V., Barr D.B., Camann D.E., Andrews H.F., Garfinkel R., Hoepner L.A., Diaz D., Dietrich J., Reyes A., Tang D., Kinney P.L., Perera F.P. (2004) Prenatal insecticide exposures and birth weight and length among an urban minority cohort. Environ. Health Perspect., 112: 1125-1132

Wilson N.K., Strauss W.J., Iroz-Elardo N., Chuang J.C. (2010) Exposures of preschool children to chlorpyrifos, diazinon, pentachlorophenol, and 2,4-dichlorophenoxyacetic acid over 3 years from 2003 to 2005: a longitudinal model. Journal of Exposure Science and Environmental Epidemiology, 20: $546-558$ 
Wolff M.S., Engel S., Berkowitz G., Teitelbaum S., Siskind J., Barr D.B., Wetmur J. (2007) Prenatal pesticide and PCB exposures and birth outcomes. Pediatr. Res., 61: 243-250

Xia Y., Han Y., Wu B., Wang S., Gu A., Lu N., Bo J., Song L., Jin N., Wang X. (2008) The relation between urinary metabolite of pyrethroid insecticides and semen quality in humans. Fertil. Steril., 89: $1743-1750$

Yeh S.P., Sung T.G., Chang C.C., Cheng W., Kuo C.M. (2005) Effects of an organophosphorus insecticide, trichlorfon, on hematological parameters of the giant freshwater prawn, Macrobrachium rosenbergii (de Man). Aquaculture, 243: 383-392

Yucra S., Gasco M., Rubio J., Gonzales G.F. (2008) Semen quality in Peruvian pesticide applicators: association between urinary organophosphate metabolites and semen parameters. Environ. Health, 7: 59 